\title{
Implementation of Regional Regulation Policy No.26 th. 2012 Concerning the Arrangement of Five Foot Traders in Banjarmasin City
}

\author{
Arifin Noor V. Rudi Handoko Arif Darmawan
}

\begin{abstract}
This research departs from the implementation of Perda N0. 26 of 2012 concerning the arrangement and empowerment of street vendors in the city of Banjarmasin. The government hopes that the city is clean, beautiful, comfortable and comfortable, the streets are well localized and well organized. The presence of street hawkers does not have as negative an impact on the environment as garbage needs. The government also agrees that street vendors are a solution for those who are looking for a better and better livelihood. Their success in carrying marginal pockets in meeting their daily needs. Thus the formulation of the problem raised regarding the implementation of the local regulation number 26 of 2012, concerning the arrangement and empowerment of street vendors in Banjarmasin? Besides that, how is the implementation model of the local regulation number 26 of 2012 , concerning the arrangement and empowerment of street vendors in Banjarmasin?Implementation of Public Policies on Privacy Policies. Research data were explored by in-depth interviews and document studies. Qualitative data analysis. The data consists of qualitative data supported by quantitative data sourced from informants and literature. The results of the study indicate that the main functions of the Government are the formulation of policies, arrangements, guidance, coordination, motivation, advocacy, mediation and control based on the principles of good governance. The results of research and discussion indicate the implementation of the Determination and Empowerment of street vendors in the city of Banjarmasin. Therefore, it is necessary to have a model that prioritizes implementation or implementation with assignments to regional apparatus organizations related to the discipline of implementing the structuring and empowerment programs of street vendors in the city of Banjarmasin. Keywords: Local Regulations, Implementation, Policy Strategies, Policy Models
\end{abstract}

DOI: $10.7176 /$ PPAR/9-10-03

Publication date:October $31^{\text {st }} 2019$

\section{INTRODUCTION}

\subsection{Background}

The success and sustainability of informal sector activities in the economic system are questioned negatively, but are more involved in the field of popular economy which is quite important in supporting community development and national development. Better, the Government's compilation program is less able to provide employment opportunities for the work sector, the informal sector with all its shortcomings is able to support as a placeholder and alternative job opportunities for job seekers show considerable economic development.

Much of the development of big cities in the third world, specifically in Southeast Asia is often not matched by the availability of adequate employment opportunities, the labor force overflow in rural areas has increased while the employment opportunities have greatly increased in search of better livelihoods. The problem of the informal sector is becoming increasingly complicated in developing countries including Indonesia because informal institutions do not support the informal sector in the true sense.Rachbini (2004: 14) proposes that at the National level the existence is very protected in the form of the 1945 Constitution and the GBHN and other legal instruments, but at the regional level in conducting daily operations discussing the discriminated and excluded informal sector. In line with this Wirutomo voiced ... "while the central policy often echoes development for poverty alleviation (poverty alleviation), on the other hand, DKI Trantip always pursues pedicab owners and street vendors who like to complain about katertiban and city care".

The above fact even sparked a wave of dissatisfaction for people who are below the poverty line, there are also those who oppose the Government's inability to develop employment opportunities in the informal sector. It should not be denied related to development policies that require large-scale assistance and can provide subsidies for the supply of cheap goods and services to support the survival of large-scale business workers, while it is allocated to the informal sector without the support of government facilities. It is still so fresh in the minds of the Indonesian people when the national finance increased setbacks due to recession, monetary crisis, but the informal sector is still able to survive without burdening the national economy, so that the community's economic wheels continue to survive, because the role of the informal sector has been growing for a long time in the ups and downs of community development and the dynamics of economic development.

The informal sector that will be discussed in this proposal is related to street vendors, which are announced to be mobile vendors. Where small-scale business units produce goods and services without a business license or location permit. The phenomenon that often appears to be some of the problems of street vendors and it has been 
a long time since on one side the Government hopes that the city is clean, beautiful, comfortable and the street vendors are localized and well organized and related. On the other hand supporting street vendors is a solution for those who looking for a better and more decent livelihood to apply for marginal pockets and to meet the basic needs of their livelihoods.

\subsection{Problem Formulation}

1. How is the implementation of the local regulation number 26 of 2012, concerning the arrangement and empowerment of street vendors in Banjarmasin?

2. What is the model for the implementation of the perda policy number 26 of 2012 , concerning structuring and empowering street vendors in Banjarmasin?

\subsection{Research Objectives}

Based on the problem formulation above, the purpose of this study is to:

1. Analyzing the implementation of the local regulation number 26 of 2012, concerning the structuring and empowerment of street vendors in Banjarmasin?

2. Determine the model for the implementation of local regulation number 26 of 2012 , concerning the structuring and empowerment of street vendors in Banjarmasin.

\subsection{Research Benefits}

1.4.1 Theoretically

This study is useful to add scientific insights on the implementation of the local regulation number 26 of 2012 , on the arrangement and empowerment of street vendors.

1.4.2 Practically.

It is hoped that this research can contribute thoughts to the government and other stakeholders regarding the implementation of the local regulation number 26 of 2012 and the model for the implementation of the local regulation number 26 of 2012, concerning the structuring and empowerment of street vendors in Banjarmasin?

\section{CONCEPT OF THOUGHT}

\subsection{Public Policy}

The term policy is often used interchangeably with other terms such as goals, programs, decisions, statutory provisions, proposals and grand designs. But for people who are outside the policy making structure these terms may be confusing. Syafiie (2006: 104), argues that policies should be charged with wisdom because wisdom is the embodiment of rules that have been set according to local circumstances and conditions by authorized personnel. For this reason, Syafiie defines public policy as a kind of answer to a problem because it will be an effort. Solve, reduce, and prevent a bad and vice versa become advocates, innovations and leaders of the occurrence of good in the best way and directed action.By understanding the opinions of the policy, at least there are some points that are important characteristics of understanding the policy, are:

1. Policy is an action taken by the government and has the aim to create prosperity for the people.

2. Policies are made through systematic stages so that all major variables of all problems will be solved.

3. Policies must be implementable by the implementing organization.

4. Policies need to be evaluated so that they are known to be successful or not in solving problems.

5. Policy is a legal product that must be obeyed and is binding on its citizens.

\subsection{Implementation}

In simple "implementation is the expansion of activities that adjust to each other" According to Syaukani et al (2004: 295) implementation is a series of activities in order to deliver policies to the public so that the policy can bring the results as expected. The series of activities include, Firstly, the preparation of a set of advanced regulations which are interpretations of the policy. Second, prepare resources to drive implementation activities including facilities and infrastructure, financial resources and of course the determination of who is responsible for carrying out these policies. Third, how to deliver policies concretely to the community.Based on this view it is known that the implementation processreal policy does not only concern the behavior of the administrative bodyresponsible for implementing the program and incurring adherence tothe target group itself, but it involves a network of political, economic, and social forces that can directly or indirectly influence the behavior of all parties involved to set direction so that public policy goals can be realized as a result of government activities. Meanwhile, according to Daniel A. Mazmanian and Paul A. Sabatier in Wahab (1997: 65) explain the meaning of this implementation by saying that understanding what actually happens after a program is declared valid or formulated is the focus of attention to the implementation of policy, namely events and activities. activities arising after the enactment of state policy guidelines, which include both efforts to administer and to have a real impact / impact on society or events. Syukur in Sumaryadi (2005: 79) states that there are three important elements in the 
implementation process, namely: (1) the existence of a program or policy that is implemented (2) the target group is the target group of people and is determined to receive benefits from the program, changes or improvements ( 3 ) implementing elements (Implementers) both organizations or individuals to be responsible for obtaining implementation and supervision of the implementation process. Implementation involves the efforts of policy makers to influence what Lipsky calls "street level bureaucrats" to provide services or regulate the behavior of the target group. For simple policies, implementation involves only one body that functions as an implementor, for example, public infrastructure development policies to help people to have a better life. Conversely for macro policies, for example, poverty reduction policies in rural areas, implementation efforts will involving various institutions, such as district bureaucracy, sub-district, village government. The success of policy implementation will be determined by many variables or factors, and each of these variables is interconnected with one another. to enrich our understanding of the various variables involved in implementation.

\subsection{Models of Public Policy Implementation}

In the study of public policy there are many models of implementation of the Edward III Model (1984: 10) proposing four factors or variables that influence the success or failure of policy implementation. The four variables or factors include variables or communication factors, resources, dispositions, and bureaucratic structure.

1. Communication Factors (Communication)

Communication is defined as the process of delivering communicator information to the communicant. Policy communication means the process of delivering policy information from policy makers to policy implementors. Public policy information needs to be conveyed to policy actors so that policy actors can know, understand what is the content, goals, direction, target groups of policies so that policy actors can prepare properly what needs to be prepared and carried out to implement public policies so that what are the goals and objectives of the policy can be achieved as expected.

\section{Resources}

Edward III (1980: 11) argues that this resource factor also has an important role in policy implementation. Edward III (1980: 11) further emphasized that "However clear and consistent the provisions or rules are, and how accurate the delivery of those provisions or rules is, if the policy implementers lack the resources to do the work. effectively, the implementation of the policy will not be effective

3. Disposition (Disposition)

Edward III (1980) asserts that the success of policy implementation is not only determined by the extent to which policy actors (implementors) know what needs to be done and are able to do it, but also is determined by the willingness of the policy actors to have a strong disposition to the policy being implemented.

4. Bureaucratic Structure (Bureaucratic Structure)

Although the resources to implement a policy are sufficient and the implementors know what and how to do it, and they have the desire to do it. But according to (Edward III, 1980: 125), the implementation of policy bias is still not effective because of inefficient bureaucratic structures (deficiencies in bureaucratic structure). This bureaucratic structure includes aspects such as organizational structure, division of authority, the relationship between organizational units in the organization concerned, and the relationship of the organization with outside organizations and so on. Therefore, the bureaucratic structure includes the dimensions of fragmentation and standard opening procedures that will facilitate and uniform the actions of policy implementers in carrying out what is their area of duty.

Based on this description, it is increasingly clear that communication variables, resources, dispositions, and bureaucratic structures influence the success rate of implementing a policy. Therefore, if public policy implementation is to be successful, the four variables need to be carried out and provided consistently and with a high sense of responsibility.

\section{RESEARCH PROCEDURE}

This study uses a descriptive method with a qualitative approach in the form of in-depth interviews with informants, Focus group discussions (FGD) and observation / document review. Use this method with the consideration that it will be as objective as possible regarding the implementation of the informal sector policy structuring and empowering street vendors in the city of Banjarmasin (Implementation of Regional Regulation number 26 of 2012, study of street vendors in the city of Banjarmasin). This method will also produce descriptive data about the results of in-depth interviews, then the data collected will be formulated in the form of a systematic written report.

Data collection in this research was carried out by using a descriptive qualitative approach (qualitative quasi), namely through in-depth interviews with designated informants as described in the research object and informant section. And also Focus group discussions (FGD) are conducted with street vendors and the community or consumers and other related parties ... Review the documents, to see the documents and things that have been done by the Banjarmasin city government.

Data analysis is the process of systematically searching and compiling data obtained from interviews, field notes 
and documentation, by organizing data into categories, describing into units, synthesizing, compiling into patterns, choosing which ones are important and which ones will be learned, and make conclusions so that they are easily understood by themselves and others. To analyze data that has been obtained through FGDs, in-depth interviews and document searches, carried out through stages.

\section{DATA AND DISCUSSION}

Based on observations and findings of existing problems, there are several important findings that become problems in the implementation of blood regulation number 26 of 2012 in Banjarmasin, namely that in this study the Banjarmasin city government has implemented a policy that has been decided, but in its implementation it can be said to be less successful, this is when viewed from the process and from the aspect of achieving goals on the basis of data obtained in the field during the research that refers to the theory developed by Edward III, the factors that led to the policy implementation of structuring and empowering street vendors in the city of Banjarmasin have not been as successful as the is expected to be explained as follows:

\subsection{Communication Factor.}

The program of structuring and empowering street vendors in the city of Banjarmasin is a program planned by the Government together with the Banjarmasin City DPRD and has been approved to be implemented. Therefore, this PKL structuring and empowerment program should be dominant in the implementation of its activities. All involved both PKL, community and related elements of the Banjarmasin city government should be actively involved in accordance with their respective duties and functions.

In its implementation, the role of the Banjarmasin city government became more dominant, especially from program financing, from the arrangement to the rejuvenation of street vendors. In the stage of fostering the stabilization of street vendors, it becomes the responsibility of the Government through the SKPD or the agency that handles it, in this case the Regional Revenue Service, the Environmental Agency (BLH), the Office of the Regional Infrastructure, the Office of Cooperative Small and Medium Enterprises (KUKMP), and the Satpol PP of the city of Banjarmasin. The division of authority must be arranged in such a way as to avoid overlapping of the main tasks. The role of the Banjarmasin city government is still not maximal, this is evident from the fact that not all street vendors have been recorded and registered, the implementation of activities seems to be only the responsibility of the regional revenue office to collect fees. This program should be the joint responsibility of all related sectors. This situation as a result of not communicating the structuring and empowerment program of street vendors to all stakeholders clearly and continuously.

The command in the implementation of the policy on structuring and empowering street vendors in the city of Banjarmasin cannot be accepted by the parties concerned clearly and continuously / consistently this situation is seen from the ignorance of the main tasks that must be carried out by each party related to their responsibilities.

In this study, it was found that in its implementation there was no clear delivery of information / orders from the regional leaders to the technical agencies tasked with organizing and empowering street vendors in the city of Banjarmasin about their duties, regional regulation number 26 of 2012 concerning the structuring and empowerment of foot traders five only said that this activity was carried out starting from data collection to rejuvenation, but in its implementation it did not specify what should be done by stakeholders, both government and private sector owners of land and street vendors so that the implementation of the structuring and empowerment program did not proceed as it should.

This study also found that some street vendors have not yet received business land which is actually used to support economic activities. Whereas with the existence of business land, residents are expected to continue to have activities and income from trading. Another thing that should be done by the Banjarmasin City Government through regional apparatus / technical service organizations has never been to intervene in activities to increase the knowledge and capabilities of street vendors, for example training on entrepreneurship, which can increase knowledge so that there is added value to the street vendors' income.

In Edward III's view, policy implementation can be successful or effective if all parties responsible for implementing the policy must know what needs to be done. Orders must be transmitted to all parties precisely, if the relevant parties do not get information or orders then of course they do not know what to do. Edward III further argued that if the policy is to be implemented as expected, then the commands in the framework of implementing the policy are not only acceptable but must also be clear, often the instructions to the policy implementor are conveyed unclear, unclear and not detailed when and how to implement the policy.

A policy can be implemented in accordance with what is expected if all orders or information relating to the implementation of the policy can not only be accepted but more importantly the order or information must be detailed and clear.so that it does not cause confusion, doubt or misunderstanding and the implementor, if the order or information submitted is not detailed and unclear, it can encourage the implementor to interpret himself on the task to be done, this is very possible conflict with the intent desired by the command giver .

Besides that, Edward III also gave the view that the order or implementation instructions in the 
implementation of the policy must be consistent, so that the implementation of the policy can be effective. Orders or instructions for implementation of policy implementation, even though they have been clearly stated, but if there are contradictory implementation instructions, it will be difficult for implementation. If the order or direction of implementing a policy is inconsistent it can certainly cause doubts and confusion from the parliamentary to determine its attitude or actions, the choice of implementor actions tends to be related to the interests of certain parties so that the policy objectives will be difficult to achieve.

\subsection{Resource Factor}

Resources is one of the important factors in the implementation of public policies, in the implementation of policies on structuring and empowering street vendors in the city of Banjarmasin it is not possible to succeed optimally without the support of the necessary resources. Resources include a broad meaning, which includes the availability of human resources, authority, facilities and infrastructure, funds and information, all of which have a contribution to the successful implementation of transmigration policies.

Regarding human resources in the arrangement and empowerment of street vendors in the city of Banjarmasin, when viewed from the aspect of quantity it is quite adequate, but when viewed from the aspect of quality, it seems to be far from expectations or inadequate. from the structural officials that are seen from the level of education everything is good because the lowest is bachelor, but not from scholars with educational backgrounds related to trade, besides that they have never attended training related to their current duties, whereas at the staff level / Implementers, both ASN and contract staff, have never attended the same technical training. This causes most of them do not have expertise in the management of street vendors in the city of Banjarmasin. This condition, of course, can hamper the implementation of the policy of structuring and empowering the street vendors, the condition of employment as a result of the frequent mutations of structural officials without regard to the official background, in addition to the growth of state civil service personnel that is not balanced with the needs and this situation is exacerbated by the existence recruitment of contract workers who do not meet the qualification requirements.

Edward III argued that staff / employees are the most essential resources in the implementation of a policy, inadequate staff / implementers become a source of failure in the implementation of public policies. Implementation of public policies is not possible to achieve maximum results without the support of adequate human resources in terms of both quantity and quality.

Besides that, Edward III also stated that this resource factor also had an important role in policy implementation. Edward III (1980: 11) further emphasized that "However clear and consistent the provisions or rules are, and how accurate the provisions or rules are conveyed are, if the policy implementers lack the resources to do the work effectively., then the implementation of the policy will not be effective ". Van Horn \& Van Matter (1974) also states that the resources as already mentioned include human resources, financial resources, and equipment resources (buildings, land equipment, and other spare parts) needed in implementing policies.

In the context of policy implementation the aspect of authority also needs to get attention, in the implementation of the policy implementation activities of structuring and empowering street vendors in the city of Banjarmasin there is no clear and explicit distribution of authority to all parties concerned, even though this authority is a power that is legally owned by the implementor in implementation Policy.

Edward III argued that implementing staff who did not have adequate authority had an impact on policy implementation. There are various forms of authority, including the authority to withdraw funds, the authority to provide financial assistance and the authority to conduct supervision. The implementation of the policy on structuring and empowering street vendors will be able to succeed to the maximum if the parties involved are given sufficient authority, so that they can carry out their duties to the maximum.

This study also found that in the arrangement and empowerment of street vendors in the city of Banjarmasin, not all the necessary information could be obtained clearly and completely by all parties concerned, the most prominent issue was information about the division of tasks between agencies as well as information about street vendors registration and data collection.

According to Edward III, information is the second aspect of an important resource factor in policy implementation, therefore if information relating to the procedures for implementing street vendor policy is not shared with all parties evenly and clearly then it can result in disruption in the implementation of the policy .

From the financing side, in this study it was also found that the very small budget provided by the Banjarmasin city government for structuring and empowerment activities that started from data collection of street vendors, street vendors registration, to the rejuvenation of street vendor locations led to less than optimal implementation of the intended policy. Though this is very necessary to improve the ability of officers and business opportunities from street vendors mentioned.

In the conditions as stated above, it can be concluded that terb 


\subsection{Bureaucratic Structure Factors}

The bureaucratic structure in the implementation of street vendors' policy and empowerment policies is assessed from aspects such as standard operating procedure aspects, some very important procedures are not implemented, causing many obstacles that are very likely to occur in the implementation of activitiesEdward III places SOP as an important element in policy implementation, where SOP is needed for similar actions in complex organizations. SOP serves to create the commitment of related parties about what is done to achieve the goals that are set together, therefore to all parties concerned to comply with the SOPs that have been set. Disposition or attitude of implementers in the implementation of public policy is one of the factors that influence the success of the implementation of public policy, the success or failure of the implementation of public policy is influenced by several factors, one of which is how the disposition / attitude of the implementers in the implementation of public policy. In implementing the policy on structuring and empowering street vendors in the city of Banjarmasin, information has been obtained that there is still disobedience to the applicable rules, lack of responsibility, and improper work morale from the implementor, the disobedience is seen from the data collection process to the rejuvenation of the street vendor locations.

In addition to disobedience to the rules, the responsibilities and morale of implementors are also still low, they throw responsibility for each other and lack sincerity in dealing with various kinds of problems in policy implementation, so that when there are problems in implementing these policies, then these problems cannot be immediately resolved. .Edward III argues that in general the implementor has discretion in carrying out his duties, so his disposition or attitude towards policy can hamper the implementation of the policy, this implies that the failure of policy implementation can be caused by the attitude of the implementor, the disposition / attitude of the implementor can be positive, neutral or negative . Positive disposition means that the parties involved support the implementation of the policy and are willing to work optimally in the hope that the implementation of the policy can achieve the expected results, while a neutral disposition if the parties involved in implementing the policy tend to be indifferent, apathetic and no matter the success or failure of a policy's implementation, negative disposition if the parties involved do not provide support for the achievement of the expected goals of a policy, they may either openly or covertly obstruct the implementation process or at least they do not want to support the activities implementation of the policy. Edward III asserted that if the implementation of a policy is expected to take place effectively, the implementor not only knows what to do and is able to carry it out but what is also important is that the implementor must have a strong will and commitment to implement the policy. The willingness factor (disposition) of the implementor has an important influence on the success or failure of the implementation of a public policy.

Edward III (1980) asserts that the success of policy implementation is not only determined by the extent to which policy actors (implementors) know what needs to be done and are able to do it, but also is determined by the willingness of the policy actors to have a strong disposition towards the policy being implemented

\subsection{Disposition factor}

Disposition or attitude of implementers in the implementation of public policy is one of the factors that influence the success of the implementation of public policy, the success or failure of the implementation of public policy is influenced by several factors, one of which is how the disposition / attitude of the implementers in the implementation of public policy. In implementing the policy on structuring and empowering street vendors in the city of Banjarmasin, information has been obtained that there is still disobedience to the applicable rules, lack of responsibility, and improper work morale from the implementor, the disobedience is seen from the data collection process to the rejuvenation of the street vendor locations.

In addition to disobedience to the rules, the responsibilities and morale of implementors are also still low, they throw responsibility for each other and lack sincerity in dealing with various kinds of problems in policy implementation, so that when there are problems in implementing these policies, then these problems cannot be immediately resolved. .Edward III argues that in general the implementor has discretion in carrying out his duties, so his disposition or attitude towards policy can hamper the implementation of the policy, this implies that the failure of policy implementation can be caused by the attitude of the implementor, the disposition / attitude of the implementor can be positive, neutral or negative. Positive disposition means that the parties involved support the implementation of the policy and are willing to work optimally in the hope that the implementation of the policy can achieve the expected results, while a neutral disposition if the parties involved in implementing the policy tend to be indifferent, apathetic and no matter the success or failure of a policy's implementation, negative disposition if the parties involved do not provide support for the achievement of the expected goals of a policy, they may either openly or covertly obstruct the implementation process or at least they do not want to support the activities implementation of the policy.Edward III asserted that if the implementation of a policy is expected to take place effectively, the implementor not only knows what to do and is able to carry it out but what is also important is that the implementor must have a strong will and commitment to implement the policy. The willingness factor (disposition) of the implementor has an important influence on the success or failure of the implementation of a 
public policy. Edward III (1980) asserts that the success of policy implementation is not only determined by the extent to which policy actors (implementors) know what needs to be done and are able to do it, but also is determined by the willingness of the policy actors to have a strong disposition towards the policy being implemented.

This disposition is the willingness, desire, and tendency of the policy actors to carry out the policy seriously so that what the policy objectives can be realized. This disposition will arise among policy makers, when it will benefit not only the organization, but also itself. They will know that the policy will benefit the organization and itself, when they are knowledgeable (cognitive) and they are very deep and understand it (Comprehension and understanding). Knowledge, deepening, and understanding of this policy will lead to acceptance (acceptance), indifference (neutrality), and reject (rejection) of the policy. That attitude will bring about the disposition of the policy actors themselves.

High disposition according to Edward III (1980) and Van Horn \& Van Matter (1974) influences the success rate of policy implementation. Disposition is defined as the tendency, desire or agreement of the implementers (implementors) to implement the policy (Edward III, 1980: 53). If policy implementation is to be effective and efficient, implementers not only know what needs to be done and have the ability to carry out the policy, but they must also have the will to implement the policy (Edward III, 1980).

\section{IMPLICATIONS AND RESEARCH FINDINGS}

In the perspective of theory development, this research can be considered as developing several theories, where research that discusses the implementation of policies on structuring and empowering street vendors in the city of Banjarmasin requires an ideal implementation model that uses several references such as public policy and policy implementation. Policy implementation in principle is how a policy can achieve its objectives, to implement public policy there are two choices that can be taken, namely directly implementing in the form of programs or through the formulation of derivative policies or derivatives of public policy (Nugroho, 2008). There are many variables that influence the successful implementation of policies that are individual or group or institution (Subarsono, 2009).

Some theories of policy implementation that can explain the role of variables that influence the success of policy implementation, such as the theory of policy implementation proposed by George C. Edward III, Daniel a. Mazmanian and Paul A. Sabatier, Marilee S. Grindle, Donald S. Van Meter and Carl E. Van Horn, Weimer and Vinning.Goerge C. Edward III (Subarsono, 2009) argues that policy implementation is influenced by four variables, namely (1) communication, (2) resources, (3) disposition, (4) bureaucratic structure. Then Donald S. Van Meter and Carl E Van Horn (Subarsono, 2009) argue that five variables affect the performance of implementation, namely (1) Standards and policy objectives, (2) resources, (3) communication between organizations and strengthening activities, (4) characteristics of the implementing agency, and (5) social, economic and political conditions. According to Weimer and Vinning (Subarsono, 2006) implementation is influenced by three variables, namely (1) the logic of the policy, (2) the policy environment, and (3) the ability of the implementor.

Structuring and empowering street vendors in the city of Banjarmasin is a policy of structuring the community's economy to encourage growth and development of the city area of Banjarmasin. In its implementation so that there is coordination and synchronization of programs between institutions, the strategy taken is to rejuvenate the location of street vendors to revive the spirit of street vendors to continue their business in an orderly manner.

The implementation of this street vendor policy is top down, this is in accordance with a review of several theories of policy implementation as proposed by Merille S. Grindle, Edward III, Mazmanian and Sabatier as well as Van Meter and Van Horn. The involvement of many regional apparatus organizations is directed at preparing human resources supporting the implementation of policies as explained in the theory of policy implementation that the resource variable is a variable that determines the success of policy implementation.

Based on the explanation above specifically the lack of successful implementation of the policies on structuring and empowering street vendors in the city of Banjarmasin is due to the lack of synergy between agencies or regional apparatus organizations that have been given authority in managing the program. Low synergy as a result of communication factors, resources, dispositions and bureaucratic structures that are not maximally implemented, in addition to the four factors above the policy implementation factors are also the determining factors for the success of the policy.

Edward III argues that communication is a process of policy transformation not only to policy implementers, but also to target groups and community social organizations (NGOs) that concentrate on policy issues. Through this communication process, the actors identified in the bureaucratic structure become clear (clarity) of what constitutes the substance of the policy, including what are the goals, objectives, and direction of the policy. With the known and understood substance of the policy it will be easier to arrange standard operating procedures (SOP) as a dimension of the bureaucratic structure. The clarity of the substance of the policy and the SOP implementing the policy make the disposition of policy actors clearer. The clearer the substance and SOP of implementing the 
policy, the easier it is for the policy actors to accept, not want to know, or reject the presence of the policy and thus encourage the emergence of one's disposition to implement the policy. Also through this communication, what resources and how much is needed is also more easily determined to implement the policy. Both human resources, information, finance, facilities and infrastructure needed in implementing the policy. The intensity and effectiveness of this policy communication are in great need of figures or leaders of public organizations who have the capability and professionalism to play their role during the policy implementation process.

\section{CONCLUSION}

The main function of the Government is the formulation of policies, arrangements, guidance, coordination, motivation, advocacy, mediation and control based on the principles of good governance. Based on the results of previous studies and discussions, several conclusions can be drawn as follows:

1. The implementation of structuring and empowering street vendors in the city of Banjarmasin was less successful due to the lack of synergy between the regional apparatus organizations designated to handle the policies on structuring and empowering the referred street vendors. It can be seen that there are many discrepancies between the expected goals and the reality in the field. Low synergy as a result of communication factors, resources, dispositions and bureaucratic structures that are not maximally implemented, in addition to the four factors mentioned above, implementation is also a determining factor for the success of government programs for structuring and empowering street vendors in the city of Banjarmasin.

2. The appropriate model in the implementation and acceleration of the implementation of the arrangement and empowerment of street vendors in the city of Banjarmasin is a model that prioritizes the implementation or implementation by assigning to the relevant regional apparatus organizations to discipline in implementing the structuring and empowerment program for street vendors in the city of Banjarmasin including PKL data collection, street vendors registration, determining the location of street vendors, removal and removal of street vendors, as well as rejuvenation of locations from existing street vendors.

\section{REFERENCES}

Ardiana Yuli Puspitasari, 2007, Pengaruh Aktivitas PKL terhadap Linkage Antara Kraton Kasunanan-Pasar Gede Surakarta, Universitas Diponegoro Semarang.

Arikunto, Suharsimi, 2010, Prosedur Penelitian Suatu pendekatan Praktek, Rineka Cipta, Jakarta.

Budiman, Bambang, 2010, Kajian Lingkungan Keberadaan Pedagang Kaki Lima di Kawasan Banjaran Kabupaten Tegal, Universitas Diponegoro Semarang.

de Soto, Hernando, 1992, Masih Ada Jalan Lain, Resolusi Tersembunyi Negara Dunia Ketiga, Yayasan Obor Indonesia, Jakarta.

Eko Handoyo, 2012, Eksistensi Pedagang Kaki Lima, Studi tentang Kontribusi Modal Sosial terhadap Eksistensi PKL di Semarang, Universitas Kristen Satya Wacana, Semarang.

Fukuyama, Francis, 1999, The End of History and The Last Man, penterjemah Amrullah, Qalam, Yogyakarta.

Jhingan, M.L., 2008, Ekonomi Pembanguan dan Perencanaan, PT. Raja Grafindo Persada, Jakarta.

Kimbal, Rahel Widyawati, 2015, Modal Sosial dan Ekonomi Industri Kecil Sebuah Studi Kualitatif, deepublish, Yogyakarya.

Manning, Amelia, 1996, Sektor Informal Perkotaan dan Kebutuhan Pokok Pedesaan, Lembaga Penelitain Universitas Muhammadiyah, Surakarta.

Wibawa, samodra, 2011, Politik Perumusan Kebijakan Publik, Graha Ilmu, Yogyakarta.

Widodo, Joko, 2016, Analsis Kebijakan Publik, Media Nusa Creative, $\quad$ Malang.

Jurnal

Ardiana Yuli Puspitasari, 2007, Tesis Pengaruh Aktivitas PKL terhadap Linkage Antara Kraton Kasunanan-Pasar Gede Surakarta, Magister Teknik Arsitektur Universitas Diponegoro Semarang.

Bambang Budiman, 2010, Tesis Kajian Lingkungan Keberadaan Pedagang Kaki Lima di Kawasan Banjaran Kabupaten Tegal, Magister Ilmu Lingkungan Universitas Diponegoro Semarang

Eko Handoyo, 2013, Eksistensi Pedagang Kaki Lima, Studi tentang Kontribusi Modal Sosial terhadap Eksistensi PKL di Semarang, Jurnal Komunitas Research \& Learning in Sociology and Anthropology, Volume 5, Nomor 2, Tahun 2013.

Fajrin, Akhmad Raditya Maulana dan Dian Rahmawati, 2016, Faktor-faktor yang berpengaruh dalam Penataan Pedagang Kaki Lima pada Koridor Jalan Pasar Besar Kota Malang, Jurnal Teknik ITS, Volume 5, Nomor 1 tahun 2016.

Ginting, Salmina W., 2004, Studi Kasus : Pengaruh Keberadaan Pedagang Kaki Lima terhadap Jumlah Pengunjung Taman Kota di Medan, Jurnal Teknik Simetrika, Volume 3, Nomor 3, Desember 2004, Halaman 203-210.

Indrianti, Weny, 2014, Perbandingan Kebijakan dan Upaya Pemerintah dalam Penertiban Pedagang Kaki Lima antara Kabupaten Berau dengan Pasar Tanah Abang Jakarta, eJournal Ilmu Pemerintahan, Volume 2, 
Nomor 4, Tahun 2014.

Ismanidar, Amirullah, Saiful Usman, 2016, Persepsi Masyarakat terhadap Pedagang kaki Lima di Kota Banda Aceh, Jurnal Ilmiah Mahasiswa Pendidikan Kewarganegaraan Unsyiah, Volume 1, Nomor 1 Agustus 2016, halalaman147-157.

Jumhur, 2015, Model Pengembangan pedangan Kaki lima (PKL) Kuliner di Kota Singkawang, Jurnal Ekonomi Bisnis dan Kewirausahaan, Volume 4 Nomor 1, halaman 125-139.

Kartasasmita, Ginanjar, 1995, Pembangunan Menuju Bangsa Yang Maju dan Mandiri: Sebuah Tinajaun Mengenai Berbagai Paradigma, Problematika dan Peran Birokrasi Dalam Pembangunan. Pidato Penganugrahan Gelar Doctor Honoris Kausa dalam Ilmu Administrasi pembangunan dari Universitas Gadjah Mada, Yokjakarta.

Madjid, Rachmawati, 2013, Dampak Kegiatan Pedagang Kaki Lima (PKL) terhadap Lingkungan di DKI Jakarta, Jurnal Ekonomi, Volume 1 Nomor 3, Mei-Agustus 2013

Mustafa, Ibrahim, 2011, Konsep Penataan Ruang Pedagang Kaki Lima di Pantai Kering Kelurahan Watampone Kecamatan Tanete Riattang kabupaten Bone, Fakultas Sains dan Teknologi Universitas Islam Negeri Alauddin Makasar.

Pusspitasari, Dinarjati Eka, 2010, Penataan Pedagang kaki Lima Kuliner untuk Mewujudkan Fungsi Tata Ruang Kota di Kota Yogyakarta dan Kabupaten Sleman, Jurnal Mimbar Hukum, Volume 22, Nomor 3, Oktober 2010, Halaman 588-606.

Rafif Ramadhan, 2007, Perubahan Sosial-Ekonomi PKL dalam Program Sentralisasi Sektor Informal Perkotaan di DTC Wonokromo 1, Jurnal Universitas Airlangga, Volume 4, Nomor 3, Maret 2015.

Ramdhan, Kurnia Muhammad, Asep Sumaryana, Slamet Usman Ismanto, 2017, Pemantauan Kebujakan Penataan pedagang kaki Lima di Kecamatan Garut Kota oleh Tim Penataan pemberdayaan Pedagang Kaki Lima Kabupaten Garut, Jurnal Administrasi Negara, Volume 2, Nomor 1, Agustus 2017.

Saputra, Rholen Bayu, Profil Pedagang Kaki Lima (PKL) yang Berjualan di Badan Jalan (Studi di Jalan Teratai dan Jalan Seroja kecamatan Senapelan), Jurnal FISIP, Volume 1 Nomor 2, Oktober 2014, Universitas Riau.

Siswadi, Yudi, 2014 Persepsi Mahasiswa tentang Keberadaan Pedagang Kaki Lima di Sekitar Kampus, Jurnal Manajemen \& Bisnis, Volume 14, Nomor 02, Oktober 2014, ISSN 1693-7619.

Sumarwanto, 2012, Pengaruh Pedagang Kaki Lima terhadap Keserasian dan Ruang Publik Kota di Semarang, Jurnal Serat Acitya Untag Semarang, Volume 1, Nomor 2, tahun 2012.

Suwandi, Joko, 2012, Pedagang Kaki Lima (PKL) di Kota Surakarta: Persepsi Masyarakat dan Alternatif Penanganannya, Jurnal Pendidikan Ilmu Sosial, Volume 22, Nomor 1, Juni 2012.

Tahir, Muchlas M., Rikasari, 2015, Penertiban Pedagang Kaki Lima (PKL) Menuju Makasar Kota Dunia, Jurnal Analisis Kebijakan dan Pelayanan Publik, Volume 1 Number 2, Desember 2015, eISSN 2527-6476

Utami, Trisni, 2010, Pemberdayaan Komunitas Sektor Informal Pedagang Kaki Lima (PKL), Suatu Alternatif penanggulangan kemiskinan, Journal of LPPM University of Sebelas Maret, Volume 25, Nomor 2 tahun 2010, ISSN 0215-9635. 